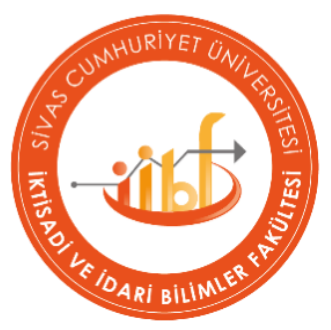

\title{
INVESTIGATION OF SELECTED COMPANIES' WEBSITES FOR ONLINE RECRUITMENT AND SUSTAINABILITY INDICATORS
}

\author{
Hasan TUTAR ${ }^{1}$ \\ Gamze AY ${ }^{2}$
}

\begin{abstract}
Sustainability is the ability to use resources rationally, follow technological developments, and show continuity in institutional change. This research analyzes the a group of selected companies' activities for sustainable human resources management through career web pages. In addition, it is aimed to analyze how they benefit from websites in electronic recruitment and innovation approaches in human resources management. The human resources and career websites analysis method developed by Cober, Brown, and Levy (2004) was used in the research. In the research, the companies' human resources and career websites included in the Borsa Istanbul (BIST) Sustainability Index for November 2019-October 2020 were analyzed. It has been determined that sustainable companies use innovative tools in human resources management (HRM), benefit from digital systems in their recruitment methods, and share information that can affect potential applicants. Organizations within the scope of the research state that they evaluate the innovative ideas of their human resources by developing innovative projects. However, sustainability reports, where employees are seen as an essential capital, may not be fully known by job applicants. Online platforms should be established to access and communicate employee and potential employee candidates to Human Resources. The era we live in is called the information age and the most important concept defining this era is change and the increase in the speed of change. We think it is necessary, even mandatory, to update their employment policies according to information technologies and move some of their activities to virtual environments. Emphasizing the importance of organizations moving their human resources functions to virtual environments makes this research unique, essential, and functional.
\end{abstract}

\author{
Article History: \\ Date submitted: \\ 13 September 2021 \\ Date accepted: \\ 21 October 2021
}

Jel Codes:

Q56, M12, O15, Q01

Keywords:

Sustainability,

Innovation,

Electronic-

Recruitment, Human

Resource

Management, Career

Websites

Suggested Citation: Tutar, H. \& Ay, G. (2021). Investigation of Selected Companies' Websites for Online Recruitment and Sustainability Indicators. Cumhuriyet University Journal of Economics and Administrative Sciences, 22(2), 456-479.

${ }^{1}$ Prof. Dr., Bolu Abant İzzet Baysal University, Faculty of Communications, Public Relations Department, hasantutar@ibu.edu.tr, ORCID ID: 0000-0001-8383-1464

${ }^{2}$ Lect. Dr., Eskişehir Osmangazi University, Vocational School of Health Services, Medical Services and Techniques Department, drgamzeay@gmail.com, ORCID ID: 0000-0003-1299-8552 
Cumhuriyet Üniversitesi

İktisadi ve İdari Bilimler Dergisi

E-ISSN: 2687-4032

2021, 22(2), pp.456-479.

Doi: 10.37880/cumuiibf.994540

\section{SEÇILMIŞ FİRMALARIN WEB SITELERININN ONLINE İŞE ALIM VE SÜRDÜRÜLEBILIRLIK GÖSTERGELERİ AÇISINDAN İNCELENMESI}

\section{Hasan TUTAR ${ }^{1}$ \\ Gamze AY ${ }^{2}$ \\ $\ddot{\mathbf{O z}}$}

Sürdürülebilirlik kaynakların rasyonel kullanımı, teknolojik gelişmenin takibi ve kurumsal değişimin süreklilik göstermesi yeteneğidir. Bu araştırmanın temel amacı, araştırma yapılan firmaların sürdürülebilir insan kaynakları yönetimi için ne tür faaliyetler yaptıklarının kariyer web sayfaları üzerinden analizini yapmaktır. Ayrıca, elektronik işe almada web sitelerinden nasıl yararlandiklarl ve insan kaynaklarl yönetiminde inovasyon yaklaşımlarının analizi amaçlanmıştır. Araştırmada, Cober et al. (2004) tarafindan geliştirilmiş insan kaynaklart ve kariyer web siteleri analiz yöntemi kullanılmıştır. Araştırmada Kasım 2019-Ekim 2020 döneminde Borsa İstanbul (BIST) Sürdürülebilirlik Endeksi'nde yer alan firmaların insan kaynakları ve kariyer web siteleri incelenip analiz edilmiştir. Sürdürülebilir firmaların insan kaynaklart yönetiminde inovatif araçlar kullandı̆̆ı, işe alım yöntemlerinde dijital sistemlerden yararlandiğ etkileyebilecek içerikte bilgi paylaşımında bulunduğu tespit edilmiştir. Araştırma kapsamındaki örgütler insan kaynağının yenilikçi fikirlerini inovatif projeler geliştirerek değerlendirdiklerini dile getirmektedirler. Ancak çalışanların önemli bir sermaye olarak görüldüğü sürdürülebilirlik raporları, iş başvurusunda bulunan adaylar tarafindan tam olarak bilinemeyebilir. Çalışan ve potansiyel çalışan adaylarına ulaşmak ve Insan Kaynaklarına iletmek için online platformlar oluşturulmalıdır. Bu araştırmadan elde edilen bilgiler, istihdam web sitesi stratejisi ve tasarımı alanında gelecekteki araştırma ve uygulamalar için yol gösterici olması yönüyle literatürdeki boşluğun doldurulmasına önemli katkı sağlayabilecektir.
Makale Geçmişi:

Iletilen Tarih:

13 Eylül 2021

Kabul Tarihi:

21 Ekim 2021

Jel Kodlart:

Q56, M12, O15, Q01

Anahtar Kelimeler:

Sürdürülebilirlik, Inovasyon, Elektronikİse Alim, Insan Kaynakları Yönetimi, Kariyer Web Siteleri

Önerilen Alıntı: Tutar, H., \& Ay, G. (2021). Seçilmiş Firmaların Web Sitelerinin Online İşe Alım ve Sürdürülebilirlik Göstergeleri Açısından İncelenmesi. Cumhuriyet Üniversitesi İktisadi ve İdari Bilimler Dergisi, 22(2), 456-479.

${ }^{1}$ Prof. Dr., Bolu Abant İzzet Baysal Üniversitesi, İletişim Fakültesi, Halkla İlişkiler ve Tanıtım Bölümü, hasantutar@ibu.edu.tr, ORCID ID: 0000-0001-8383-1464

${ }^{2}$ Öğr. Gör. Dr., Eskişehir Osmangazi Üniversitesi, Sağlık Hizmetleri Meslek Yüksekokulu, Tibbi Hizmetler ve Teknikler Bölümü, drgamzeay@ gmail.com, ORCID ID: 0000-0003-1299-8552 


\section{INVESTIGATION OF SELECTED COMPANIES' WEBSITES FOR ONLINE RECRUITMENT AND SUSTAINABILITY INDICATORS}

\section{INTRODUCTION}

Sustainability is the ability to perpetuate, and it also refers to perpetuating the civilization attained by humanity in the 21st century. The concept of sustainability is also used for not exploiting resources, directing technological development, directing investments, and maintaining institutional change in harmony. It is also used to ensure balanced development in which the potential of resources to meet human needs and wants is preserved (Capra, 2015; James et al., 2015; Mage et al., 2013). The Sustainable Development Goals are set in the international development goals series of the United Nations General Assembly. In the Official Agenda for Sustainable Development adopted on September 25, 2015, 17 Sustainable Development Goals and 169 associated sub-goals were identified. The 17 development goals of sustainability have been determined as follows (undp.org): Poverty, food, health, education, women's issues, water and sewerage services, energy, economic problems, infrastructure problems, inequality, settlement, consumption, climate, marine life, ecosystems, institutions, and sustainability. It is emphasized that implementation tools should be developed to achieve these goals. This research has been developed depending on the institution's parameter of sustainability determined by the United Nations. The main objective of corporate sustainability has been to promote peaceful and inclusive services, ensure everyone's access to justice, and establish effective, accountable, and inclusive institutions at all levels. For this purpose, the types of activities developed by the institutions, the research sample, were analyzed through the companies' websites with the BIST sustainability index.

Corporate websites are an essential source of information for job seekers. Many web pages are used jointly by organizations and developed digitally. Therefore, it is assumed that organizations can influence the qualified workforce through their web pages. In this way, companies think that they can shape the perceptions of the candidates in the direction they want (Richard et al., 2004; Breaugh and Starke, 2000). Although there have been significant publications on corporate sustainability determined by the United Nations, it can be mentioned that there is a gap in the literature on web pages and sustainable human resources, especially in a period when applications such as e-business, virtual business, and digital business have become commonplace. The sample of this research consists of companies included in the sustainability index in the BIST list. To increase employees' competencies, training, and development, important criterion incorporating sustainability was monitored. For corporate sustainability, it is of great importance to determine the human resource development strategies of organizations. Therefore, it can be argued that this research is up-to-date, functional, and essential in emphasizing the importance of web pages in employee recruitment, training, and development.

In this research, BIST "Sustainability Index" was used to determine sustainability in the companies that constitute the research sample. The importance of sustainability for companies is to show that they have an investment-grade index to attract capital and provide financing. With the index, a performance evaluation tool was also presented to make improvements and set new targets. Another use of the sustainability index is that it provides the opportunity to develop measurable risk management skills (Orsato et al., 2015; Batista and Francisco, 2018; Chams and Garsia, 2019). It is thought that this will create a competitive opportunity for the companies, and the public awareness and reputation of the companies included in the index will be high. Therefore, the companies that make up the sample of this research are companies with high recognition in the sector.

Information about the services offered by companies in human resources and career management web pages is essential for candidates who want to apply for a job. In this research, 
Hasan TUTAR \& Gamze AY, 2021 Cilt: 22, Sayl: 2, ss.456-479.

career websites were analyzed in terms of the sustainability of human resources policies. For this purpose, various suggestions were made by focusing on the qualitative analysis of the information shared on human resources and career websites. Examining the human resources and career websites of sustainable companies is essential in filling the gap in the literature and contributing to the practice. In this context, the research will try to answer the basic question, "What is the role of web content of digital innovation in sustainable human resources management." In addition, depending on this fundamental question, the following sub-questions were tried to be answered:

1 - What are the content features of the career websites of sustainable companies?

2- What are the interactive features of career websites of sustainable companies?

3- What are the standard features of career websites of sustainable companies?

\section{CONCEPTUAL FRAMEWORK}

\section{1. Sustainability in Human Resources Management}

In sustainable HRM, it is also expected to treat employees as socially responsible individuals as an ethical value. Another purpose of sustainable HRM is to increase the well-being of employees and reduce the negative impact of work on employees. For this purpose, it is seen that the most frequently repeated expressions within the framework of HRM in sustainability reports: occupational health and safety, talent management, diversity management, performance evaluation, employee satisfaction, and loyalty, work and life balance, and internal communication themes are most repeated in the business and management sector (Esen and Süral Özer, 2020; Ehnert, 2009; Esen and Esen, 2018). One of the essential work areas for companies within sustainable human resources management is electronic recruitment (e-recruitment) applications, an innovative application, especially during pandemic days. Innovative web pages should be prepared for such applications. Electronic recruitment is essential in reducing costs and making it easier for people in different places to apply for a job. Within the scope of Sustainable Human Resources Management, Themes such as employee satisfaction, subjective well-being, voluntary participation, work-life balance, career management, and green practices are used.

Taylor et al. (2012) stated that one of the leading indicators of human resources management success is sustainability. For this, organizations should hire competent people who can think innovatively (Srivastava and Bhatnagar, 2008). Innovativeness of employees, one of the primary sources of sustainability in human resources, requires a competency-based management approach (Waheed et al., 2019, Tutar, 2015). However, adequate human resources can be possible with competent people and human resources that give them the necessary initiative (Ma Prieto and Pilar PérezSantana, 2014).

There is always a linear relationship between human resources practices and organizational sustainability because it is not possible to achieve organizational goals and objectives with insufficient human resources. The most important guarantee of organizational sustainability is sustainable human resources practices. A flourishing human resources application can only be possible with a management approach that has innovative thoughts and encourages innovation (Dwivedi et al., 2021). In addition to these, another aspect is an understanding of the innovative culture that spreads throughout the organization. A core staff and all human resources in the organization should have adopted the innovative culture (Bilan et al., 2020). Organizational innovation and sustainable human resources practices are the essential tools of organizational 


\section{INVESTIGATION OF SELECTED COMPANIES' WEBSITES FOR ONLINE RECRUITMENT AND SUSTAINABILITY INDICATORS}

sustainability. For this, organizations need to apply creativity as a strategy with innovative human resources practices (Cho et al., 2019).

\subsection{Online recruitment and sustainability}

Online recruitment, e-recruitment, or web-based recruitment uses innovative online technology to assist candidates in the recruitment process. Online recruitment uses a firm's website, third-party job sites, resumes databases, search engine marketing, or social media platforms to fill vacancies. Web-based recruitment provides convenience to applicants and recruitment organizations regarding time and cost (Thompson et al., 2008; Kapse et al., 2012; Cappelli, 2001). Since corporate websites are the first place many people look when evaluating potential employers, these pages must be functional.

The possibility of unlimited sharing of information has a profound effect on business life. In the recruitment process, which is the function of human resources management, the integration of new technologies into operational processes can be regarded as essential for the system's functionality. A pool of resumes of millions of candidates can be created through the websites of private employment agencies and the online employment platforms of which they are members. Thanks to the widespread and development of internet technology, people's job search and evaluation of job applications provide great convenience. To attract the attention of potential candidates, companies need to develop human resources websites in terms of content, image, language, and diversity (Lebekwe and Güran, 2018).

Web pages of companies play a critical role in the electronic recruitment process to ensure the application of qualified people. E-recruitment provides excellent convenience for candidates as it is independent of time and place through technology to identify, recruit and influence competent candidates (Holm, 2012). When the effective e-recruitment technique recruits the potential workforce, it is possible to use these pages for training and development after employment (Mishra and Kumar, 2019; Zusman and Landis, 2002). In terms of both form and functionality of online recruitment materials, it increases the motivation of qualified people to apply for a job. In some studies, focusing on the subject and employers' impressions, it has been determined that there is a strong correlation between website satisfaction and organizational commitment, especially continuance commitment (Zusman and Landis, 2002; Thompson et al., 2008).

The interplay of form, content, and function on career web pages is critical to website success. For this, companies need to make creative innovations in communicating messages that significantly affect potential applicants. Messages to applicants must be relevant to the overall purpose of the company. The impact of websites used in recruitment also needs to be evaluated (Coper, 2004: 211; Wołodźko and Woźniak, 2017; Bejtkovský et al., 2018). Finally, investments in digital infrastructure such as communication and information technologies are of great importance in terms of human capital, competitive advantage, and companies' sustainability.

\subsection{Sustainability and Digital Innovation}

Sustainability has many aspects; one of them is sustainable human resources management. For this reason, it can be argued that the present research will contribute to the determination of what sustainable human resources policies should be. The web pages discussed here are essential for the applicants, indicating the companies' human resources policies. Considering that it is not practical to involve too many people in development programs simultaneously, in times of crisis such as a pandemic, it can be argued that companies' web pages are essential not only for recruitment but also for training and training development of human resources. For this reason, 
innovative page designs of companies in terms of procurement, training, and development, and other functions of human resources management are significant for the sustainability of human resources (Cober et al., 2003; Palmer, 2002; Williamson et al., 2003). Sharing new ideas on information-sharing platforms and developing innovative applications in production and service is of great importance in reducing costs, increasing competitiveness, and, therefore, in sustainable human resources. It can be argued that it would be beneficial to see human resources and career web pages as a digital sharing area for procurement, training and development, and organizational creativity, and collective mind production (Taylor, 2002; Bednarczuk and Wendebug, 2018)

In a highly competitive environment where the shelf life of products is shortened, innovation is an effective tool for companies to increase their competitiveness (Junior et al., 2018). Organization for Economic Co-operation and Development (OECD) innovation; A new or improved product or process should be materially different from the unit's previous products or processes, offered to potential users or made available by the unit. Sustainability is essential in drawing attention not only to economic but also to climate and environmental sustainability in the intensely competitive environment of companies. Innovative products that respect the environment are essential in dealing with economic and ecological crises (Melane-Lavado and Álvarez-Herranz, 2018). The relationship between innovation and sustainability is expressed with the concept of "sustainable innovation." Therefore, innovation is seen as an essential tool in achieving sustainability. For this reason, as in the literature, innovation has been examined together with sustainability in the present research (Maier and Gavris, 2020; Lazaretti et al., 2018).

Human capital is essential for innovation. To develop new products in sustainable companies, employees need to develop their entrepreneurial characteristics. For this, bringing employees together in online platforms through HRM and career web pages is of great importance in creating creative ideas (Souza et al., 2020; Veloso et al., 2020). Innovation, developmentoriented policies, and technological competencies are developed in organizations, and thus, sustainable organizational innovation has a high potential to transform technology, products, and the market. The innovation ability also has a high potential to create a competitive advantage for companies. Sustainability is of great importance wherever scarce resources are concerned. Balancing the measured use and reproduction of resources is essential in sustainability in a competitive market (Lazarettti et al., 2018; Kamal, 2020; Mauri-Castello et al., 2019). While financial and economic factors are important in companies' sustainability, human resources competence is essential.

The driving effect of globalization, the aging of the workforce, developments in the market, increasing risk factors, intensive work schedules necessitate a re-examination of human resources within the sustainability framework. New generation employment contracts, lack of job security, heavy emotional burden at work, work-life imbalance increase the importance of sustainable human resources (Ehnert, 2009; Van Stolk et al., 2012). The necessity of establishing innovative organizations to increase the competitiveness of companies necessitates sustainable human resources management. Learning and developing human resources is of great importance for the development of innovative knowledge in organizations. Adopting sustainable human resource management provides better performance and greater resilience to the organization in the long run. Sustainability is also necessary to improve the quality of life (Zang et al., 2019; Esen and Süral Özer, 2020; Esfahani et al., 2016; Mauri-Castello et al., 2019; Kamal, 2020). To talk about sustainable human resources management, practices related to HRM should be considered in terms of ecology and social elements, apart from the economy. Therefore, sustainability principles should 


\section{INVESTIGATION OF SELECTED COMPANIES' WEBSITES FOR ONLINE RECRUITMENT AND SUSTAINABILITY INDICATORS}

be considered with economic, ecological, and human resources policies (Esen and Esen, 2018; Melane-Lavado and Álvarez-Herranz, 2018).

\section{METHODOLOGY}

In the present research, the examination of the career websites of corporate companies developed by Cober et al. (2004, Tutar and Erdem, 2020) was used. In the research, human resources and career websites of companies included in the Borsa Istanbul (BIST) Sustainability Index were examined, as they were suitable for the purpose and questions of the research. Cober et al. (2004) analyzed a career website; in terms of content, function, and form. In this research, the companies' web page makeup samples were examined regarding the content in question. The BIST Sustainability Index has been created that includes companies traded in Borsa Istanbul and whose corporate sustainability performances are high (https://www.borsaistanbul.com/tr/). As of November 4, 2014, this index has been calculated and published as price and income with the code XUSRD. There is an index period per year, from November to October. For the index, which started with valuation of the companies included in the BIST 30 index in 2014, companies in BIST Sustainability indices were evaluated as of 2019. The list of evaluated companies is renewed every year and announced by Borsa Istanbul.

The BIST index reveals how companies approach important sustainability-related issues such as global warming, depletion of natural resources, clean drinking water, health, safety, and employment. The index allows companies to compare their corporate sustainability performance locally and globally. With the index, a performance evaluation tool is also offered to make improvements and set new targets. The index establishes a relationship between transparency, accountability, and sustainability. The index provides a tool for investors to distinguish companies that adopt the principles of sustainability and corporate social responsibility and invest in these companies. The index also provides an indicator for issuing financial products such as funds based on sustainability principles, exchange-traded funds, and structured products (https://www.borsaistanbul.com/tr/page/165/bist-sustainability-index).

Table 1: Companies in Borsa Istanbul (BIST) Sustainability Index in 2020

\begin{tabular}{|c|c|c|c|}
\hline Range & Company name & Range & Company Name \\
\hline 1. & Anadolu Grubu Holding Corporation & 30 & Logo Yazılım Sanayi ve Ticaret Corporation \\
\hline 2. & Akbank Corporation & 31 & Migros Ticaret Corporation \\
\hline 3. & Ak Enerji Elektrik Üretim Corporation & 32 & Netaş Telekomünikasyon Corporation \\
\hline 4. & $\begin{array}{l}\text { Aksa Akrilik Kimya Sanayi } \\
\text { Corporation }\end{array}$ & 33 & Otokar Otomotiv ve Savunma Sanayi Corporation \\
\hline 5. & Aksa Enerji Üretim Corporation & 34 & Pegasus Hava Taşımacılığı Corporation \\
\hline 6. & $\begin{array}{l}\text { Albaraka Türk Katılım Bankası } \\
\text { Corporation }\end{array}$ & 35 & Petkim Petrokimya Holding Corporation \\
\hline 7. & $\begin{array}{l}\text { Anadolu Efes Biracilık ve Malt Sanayi } \\
\text { Corporation }\end{array}$ & 36 & Polisan Holding Corporation \\
\hline 8. & Anadolu Hayat Emeklilik Corporation & 37 & Şekerbank Corporation \\
\hline 9. & $\begin{array}{l}\text { Anel Elektrik Proje Taahhüt ve Ticaret } \\
\text { Corporation }\end{array}$ & 38 & Şok Marketler Ticaret Corporation \\
\hline 10. & Arçelik Corporation & 39 & Tat Gida Sanayi Corporation \\
\hline
\end{tabular}


Hasan TUTAR \& Gamze AY, 2021 Cilt: 22, Sayl: 2, ss.456-479.

\begin{tabular}{|c|c|c|c|}
\hline 11. & $\begin{array}{l}\text { Aselsan Elektronik Sanayi Ve Ticaret } \\
\text { Corporation }\end{array}$ & 40 & Tav Havalimanları Holding Corporation \\
\hline 12. & Aygaz Corporation & 41 & Tekfen Holding Corporation \\
\hline 3 & $\begin{array}{l}\text { Bizim Toptan Satış Mağazaları } \\
\text { Corporation }\end{array}$ & 42 & Tofaş Türk Otomobil Fabrikası Corporation \\
\hline 14. & $\begin{array}{l}\text { Brisa Bridgestone Sabanc1 Lastik } \\
\text { Sanayi ve Ticaret Corporation }\end{array}$ & 43 & Turkcell İletişim Hizmetleri Corporation \\
\hline 15. & Coca-Cola İçecek Corporation & 44 & Tüpraş-Türkiye Petrol Rafinerileri Corporation \\
\hline 16. & $\begin{array}{l}\text { Çimsa Çimento Sanayi ve Ticaret } \\
\text { Corporation }\end{array}$ & 45 & Türk Hava Yolları Corporation \\
\hline 17. & $\begin{array}{l}\text { Doğan Firmalar Grubu Holding } \\
\text { Corporation }\end{array}$ & 46 & Türk Telekomünikasyon Corporation \\
\hline 18. & $\begin{array}{l}\text { Doğuş Otomotiv Servis Ve Ticaret } \\
\text { Corporation }\end{array}$ & 47 & Türk Traktör ve Ziraat Makineleri Corporation \\
\hline 19. & Enerjisa Enerji Corporation & 48 & Türkiye Garanti Bankası Corporation \\
\hline 20. & Enka İnşaat ve Sanayi Corporation & 49 & Türkiye Halk Bankası Corporation \\
\hline 21. & $\begin{array}{l}\text { Ereğli Demir ve Çelik Fabrikaları } \\
\text { Corporation }\end{array}$ & 50 & Türkiye İş Bankası Corporation \\
\hline 22. & Ford Otomotiv Sanayi Corporation & 51 & Türkiye Sınai Kalkınma Bankası Corporation \\
\hline 23. & Global Yatırım Holding Corporation & 52 & Türkiye Şişe ve Cam Fabrikaları Corporation \\
\hline 24. & $\begin{array}{l}\text { Hac1 Ömer Sabanc1 Holding } \\
\text { Corporation }\end{array}$ & 53 & Türkiye Vakıflar Bankası Corporation \\
\hline 25. & İskenderun Demir ve Çelik Corporation & 54 & Ülker Bisküvi Sanayi Corporation \\
\hline 26. & $\begin{array}{l}\text { Kardemir Karabük Demir Çelik Sanayi } \\
\text { Ve Ticaret Corporation }\end{array}$ & 55 & Vestel Beyaz Eşya Sanayi ve Ticaret Corporation \\
\hline 27. & $\begin{array}{l}\text { Kerevitaş Gida Sanayi ve Ticaret } \\
\text { Corporation }\end{array}$ & 56 & Vestel Elektronik Sanayi ve Ticaret Corporation \\
\hline 28. & Koç Holding Corporation & 57 & Yap1 ve Kredi Bankas1 Corporation \\
\hline 29. & Kordsa Teknik Tekstil Corporation & 58 & Zorlu Enerji Elektrik Üretim Corporation \\
\hline
\end{tabular}

Kaynak: https://www.kap.org.tr/tr/Endeksler

\section{FINDINGS}

\subsection{Contextual Analysis of Websites Used in E-recruitment}

The human resources and career pages of 58 companies in the BIST sustainability index list were analyzed in terms of form, content, and functionality. In this context, the content related to work-related wages and workplace opportunities, culture, training and development opportunities, and job-related responsibilities on the organizations' human resources and career web pages were examined. $69 \%$ of organizations briefly mentioned a remuneration policy. Organizations stated that they determine the remuneration according to collective bargaining agreements, unions, market conditions, and performance and rewarding criteria. Although some companies mentioned the bonuses made throughout the year, no company mentioned the income earned. Therefore, an indication of fees may be preferable. The rate of mentioning social opportunities other than wages such as nursery, transportation, meals, communication, and annual leave due to working hours, social activity areas, private health insurance, and occupational health insurance is $79 \%$. Since these opportunities are included in more detail according to the content of remuneration, it examined different factors. 


\section{INVESTIGATION OF SELECTED COMPANIES' WEBSITES FOR ONLINE RECRUITMENT AND SUSTAINABILITY INDICATORS}

Organizational culture, including organizational values, norms, and principles in the working environment, is mentioned in the websites examined. It has been stated that human resources are an essential capital. $97 \%$ of businesses mentioned career opportunities of their employees. It is stated on the companies' websites that development of employees is given importance with the opportunities provided inside and outside the organization. Some international companies have tried to be preferable by mentioning the employment opportunities in their branches abroad. On the companies' websites, opportunities such as education abroad, online education websites, and rotation in centers abroad are mentioned within education and career opportunities. Only $32 \%$ of these sites include the definitions and responsibilities of the jobs to be done. Some websites describe a typical working day, and some share videos featuring employees. Students and new graduates who want to work in these companies are given information about their areas to improve themselves.

Under the heading of compatibility, $81 \%$ of the websites contain information groups under the links of students, recent graduates, professionals, or experienced. In this way, those who want to do an internship examine employment conditions before graduation, and those who work in other companies are informed about opportunities. Social programs and fun activities that can help manage work-life balance are emphasized. $69 \%$ of the companies surveyed stated that they do not look at employment only with the profit motive and include various programs to make their employees feel satisfied. $76 \%$ of the companies mentioned that they offer equal employment opportunities. Issues such as gender equality and racial discrimination are also shared on the websites under ethical principles. To show the diversified business environment, messages such as the number of employees, education levels, age groups, male-female ratio, and average working hours are included. The statements that the employees other than the executive group shared their experiences were found in $36 \%$. Video recordings often supplement such information.

$59 \%$ of the companies surveyed mentioned the self-assessment tests, ability tests, general tests, and foreign language knowledge they applied during the evaluation processes of the candidates. This information is generally obtained from the sections where the application processes are specified. However, only the names of these self-assessment tests are included. No general information is given about its contents. The number of companies that provide information about their voluntary services related to social responsibility is $91 \%$. The companies surveyed generally gave information on their websites reporting that they attach importance to art, culture, and sports by opening sports clubs, being members of various groups, supporting those in need, and providing scholarships through their established foundations. In addition, they stated in their sustainability reports that they carry out their activities in a manner not disturbing the ecological balance. They also stated that they carry out various social responsibility projects. In addition, they stated that they carry out social responsibility projects within the scope of sustainable resources.

Most of the companies included in the index provide services at an international level. Although the English language is the majority, job application forms are prepared in several foreign languages on the websites. It is important to renew the employees' technology to develop new ideas from digital opportunities. Examples of various creative suggestions of employees contributing to the company's sustainability are included on digital platforms where employees' opinions can be obtained. In addition, they organize events bringing professionals, industrialists, academics, and university students in Turkey and the world together and providing them opportunities to encounter their innovative activities. Every year, Turkey's Innovation Leaders are selected under the name of "InovaLIG." With "InovaLIG," companies compete based on their innovative competencies. The 
Hasan TUTAR \& Gamze AY, 2021 Cilt: 22, Sayl: 2, ss.456-479.

companies analyzed in the present research have also participated in this competition and received awards. One of the successful examples of these companies in innovation is Akbank, which operates in finance. At Akbank, all employees are included in innovation processes for sustainability. All Akbank employees who have an innovative project idea share their ideas with the "Akbank Lab," Companies supporting these ideas are contacted to implement them.

Table 2: Characteristics of Sustainable Firms' Career Websites

\begin{tabular}{|c|c|c|}
\hline $\begin{array}{l}\text { Employment } \\
\text { Information }\end{array}$ & Disclosures & $\begin{array}{c}\text { Number of } \\
\text { websites }\end{array}$ \\
\hline Pricing & Information on wages and benefits. & 40 \\
\hline $\begin{array}{l}\text { Side incomes and } \\
\text { benefits. }\end{array}$ & $\begin{array}{l}\text { Information related to the position is announced on the } \\
\text { website. }\end{array}$ & 46 \\
\hline Culture & $\begin{array}{l}\text { Information about organizational culture, values, goals, and } \\
\text { work environment. }\end{array}$ & 58 \\
\hline \multirow{3}{*}{$\begin{array}{l}\text { Education } \\
\text { Preliminary } \\
\text { information about } \\
\text { the job. }\end{array}$} & Information on education and career development. & 56 \\
\hline & $\begin{array}{l}\text { Other than the job posting, information describing a typical } \\
\text { working day or responsibilities of an employee at the firm. }\end{array}$ & 19 \\
\hline & \multicolumn{2}{|l|}{ Information Related to Sustainability Compliance. } \\
\hline $\begin{array}{l}\text { Information about } \\
\text { specific groups. }\end{array}$ & $\begin{array}{l}\text { Sections of the website for navigating the website by certain } \\
\text { groups of applicants (e.g., college students, experienced } \\
\text { workers). }\end{array}$ & 47 \\
\hline $\begin{array}{l}\text { Information About } \\
\text { Working Life. }\end{array}$ & $\begin{array}{l}\text { Programs designed to improve the work and private lives of } \\
\text { employees. }\end{array}$ & 40 \\
\hline $\begin{array}{l}\text { Information on } \\
\text { employee diversity. }\end{array}$ & $\begin{array}{l}\text { Information on EEO (equal employment opportunity) and } \\
\text { promoting workforce diversity by ethnicity and gender. }\end{array}$ & 44 \\
\hline $\begin{array}{l}\text { Case study } \\
\text { testimonies of } \\
\text { employees. }\end{array}$ & $\begin{array}{l}\text { Information on the work experience of employees on the } \\
\text { website. }\end{array}$ & 21 \\
\hline $\begin{array}{l}\text { Self-Assessment } \\
\text { criteria. }\end{array}$ & $\begin{array}{l}\text { Information on the results of the surveys made about the } \\
\text { employees and the company. Information about desired } \\
\text { characteristics in employees and interactive cultural } \\
\text { adaptation inventories. }\end{array}$ & 34 \\
\hline $\begin{array}{l}\text { Social } \\
\text { Responsibilities. }\end{array}$ & $\begin{array}{l}\text { Information on corporate philanthropy and employee } \\
\text { outreach services. }\end{array}$ & 53 \\
\hline
\end{tabular}

Within the scope of innovation, some sustainable companies establish innovation centers in other countries and try to achieve innovative initiatives by sending their employees to these centers at certain times. For example, the defense industry company ASELSAN encourages its employees to increase the ratio of engineers with masters and doctorate degrees working in R\&D centers. There are many personnel in these centers, and digital transformation is constantly emphasized as a priority goal. To obtain innovations from the ideas of the employees, competitions 


\section{INVESTIGATION OF SELECTED COMPANIES' WEBSITES FOR ONLINE RECRUITMENT AND SUSTAINABILITY INDICATORS}

are organized, and projects based on these ideas are developed. Innovative ideas obtained from these projects are used as a product and service development strategy as an end result. Sustainable companies state that they consider innovation as their priority target. It is emphasized that sustainability can be achieved to the extent of a firm's innovation ability.

\subsection{Usability and Interaction Analysis of the Career Website}

57 of the 58 companies on the sustainability website included in the research have a human resources or career page and a menu link. One remaining firm stated that it accepts job applications in the form of e-mail transmission. Fifty-four companies have second-level navigation on the career or human resources page. Thirty-nine companies have website third-level navigation, that is, additional navigational links. In general, companies with more information content have third-level connections. Mostly, it is seen that a new job application tab is redirected through these links. Fiftythree companies accept online applications. Candidates can send their CVs to six companies via email. Only three companies accept both an online application and e-mail submission. The website kariyer.net can be used to make digital applications on all websites. All companies use third-party online application services.

Table 3: Availability and Interaction of the Companies' Career Website

\begin{tabular}{|c|c|c|}
\hline Interactivity & Descriptions. & $\begin{array}{l}\text { Number of } \\
\text { Websites. }\end{array}$ \\
\hline Menu link. & $\begin{array}{l}\text { Some main navigation tools or menu links are available on } \\
\text { career websites. }\end{array}$ & 57 \\
\hline $\begin{array}{l}\text { Second level } \\
\text { navigation. }\end{array}$ & $\begin{array}{l}\text { Unique navigational links on websites facilitate the movement } \\
\text { towards information in a certain section (For example: } \\
\text { Accessing the 'Witness' page by going from the home page to } \\
\text { the 'Why should you work with us' page). }\end{array}$ & 54 \\
\hline $\begin{array}{l}\text { Third-level } \\
\text { navigation. }\end{array}$ & $\begin{array}{l}\text { Additional navigational links at the bottom of the website (For } \\
\text { example, Access specific employee experiences and insights } \\
\text { from the homepage, 'Why should you work with us' and } \\
\text { 'Witness' pages). }\end{array}$ & 39 \\
\hline \multicolumn{3}{|c|}{ Online Application Form. } \\
\hline $\begin{array}{l}\text { Online } \\
\text { application. }\end{array}$ & $\begin{array}{l}\text { The application can be made directly from the website of the } \\
\text { website. E-mail addresses provided by the organization are not } \\
\text { accepted as an application mechanism. }\end{array}$ & 53 \\
\hline $\begin{array}{l}\text { E-mail } \\
\text { Application. }\end{array}$ & $\begin{array}{l}\text { Candidates can send their CVs to the e-mail addresses provided } \\
\text { for submission. }\end{array}$ & 6 \\
\hline $\begin{array}{l}\text { Online application } \\
\text { information. }\end{array}$ & $\begin{array}{l}\text { Statements of applicants' expectations regarding the process of } \\
\text { processing their CV submissions. }\end{array}$ & 24 \\
\hline
\end{tabular}


Hasan TUTAR \& Gamze AY, 2021 Cilt: 22, Sayl: 2, ss.456-479.

\begin{tabular}{llr}
$\begin{array}{l}\text { Application } \\
\text { process } \\
\text { information. }\end{array}$ & $\begin{array}{l}\text { Information on the website describing at least one recruitment } \\
\text { process (e.g., interview, CV preparation). }\end{array}$ & 39 \\
$\begin{array}{l}\text { Career.net } \\
\text { application. }\end{array}$ & The application can be made on the digital career website. & 57 \\
\hline
\end{tabular}

Twenty-four of the companies make explanatory statements to the candidates about the stage in the online application process. Some companies accept general applications and state that they will evaluate the resumes for open positions. Thirty-nine of the companies provide information about the application process. Candidates who will apply can see which processes they can go through to be accepted to the job. Some companies prefer to explain this by drawing a diagram or figure - some prefer text-based narration. In the text-based narratives, the conditions to be taken to evaluate candidates are mentioned more. All companies accept applications through third-party digital career websites, except for their websites. Companies are trying to attract human resources from the web page kariyer.net within the scope of digital innovation.

\subsection{Analysis of Formatting Features of the Website}

Visual elements were included on the websites of $91 \%$ of the companies in the sample group. The subjects that are particularly emphasized on the websites are made through videos where employees share their experiences, images of the products produced, pictures of entertaining events inside and outside the organization, and images of the working environment. With these visual elements, it is aimed to create a positive perception in the selection of human resources. The messages conveyed on the websites where these elements are used are prepared in a more comprehensible form. It becomes difficult to understand the messages on websites that are used entirely with text content. 98\% of the companies used different images and different colored backgrounds - $27 \%$ of companies used moving pictures and links. Video recording was used on $64 \%$ of websites. In these video recordings, some videos convey organizational introductions, videos containing employee experiences, activities within the scope of social responsibility, and fun work environment opportunities that can provide work-life balance.

Table 4: Analysis of Characteristics of Web Site Formatting

\begin{tabular}{|c|c|c|}
\hline $\begin{array}{l}\text { Vividness/ } \\
\text { Brightness }\end{array}$ & Description & $\begin{array}{c}\text { Number } \\
\text { of } \\
\text { Websites }\end{array}$ \\
\hline Pictures. & $\begin{array}{l}\text { Pictures of people, objects, and awards are found on the } \\
\text { website. }\end{array}$ & 53 \\
\hline Color. & $\begin{array}{l}\text { Distinctive colors are used to highlight background, graphic, } \\
\text { or image aspects on the website. }\end{array}$ & 57 \\
\hline Animation. & Animated graphics, images, or links on the website. & 16 \\
\hline Audio/Video. & Video or audio messages are available on the website. & 37 \\
\hline Diverse Pictures. & $\begin{array}{l}\text { Pictures of people of apparently different races are found on } \\
\text { the website. }\end{array}$ & 5 \\
\hline
\end{tabular}




\section{INVESTIGATION OF SELECTED COMPANIES' WEBSITES FOR ONLINE RECRUITMENT AND SUSTAINABILITY INDICATORS}

Messages regarding diversification and ethical principles were included in $76 \%$ of the companies. In the pictures that show diversity, there are gender and age differences, pictures of white-collar and blue-collar employees. Only 5\% of the companies featured pictures of people from different ethnicities. Although it is difficult to directly understand the different ethnic characteristics when the images of people on the websites are examined, they must emphasize differences. Emphasizing the level of competence in racially diversified website contents is a common situation from professional company management. 
Hasan TUTAR \& Gamze AY, 2021 Cilt: 22, Sayl: 2, ss.456-479.

\section{DISCUSSION AND CONCLUSION}

In this research, online recruitment practices of sustainable organizations within the scope of digital innovation were analyzed. It is essential for researchers and practitioners interested in electronically innovated Web-based recruitment practices to create high-quality human resource pools. The companies formed the sample; the snapshot was analyzed in form, content, and functionality. These factors have been used to form a basis for websites' relationship with sustainability. In addition, the shares of the companies in the research about their innovation studies were examined. It has been determined that some of the sustainable companies' web pages lack information about wages and additional incomes and rights, job descriptions, entertaining aspects of working life that can help work and social life harmony, opinions of staff about their experiences, and self-evaluation tools. In addition, it has been determined that companies present some information about themselves, such as culture, education, diversity, and social responsibility, on their web pages, but they give less information about wages and other material rights.

Theoretical implications. Sustainable human resources are not just a recruitment practice. On the contrary, the understanding of sustainable human resources covers all the functions of human resources management. In this context, all processes such as recruitment, selection and recruitment, occupational health and safety, training and development, talent management, career planning, internal communication, human resources strategy and HR planning, performance evaluation, wage management, industrial relations and collective agreements, job design, and job analysis constitute sustainable human resources. Sustainable practices that can provide change through benevolence, social integration, competencies, and career development are also related to sustainable human resources (Guerci \& Pedrini, 2014; Özgül \& Gürol, 2019). Another aspect of "sustainable human resources" is that it is directly related to organizational innovation. For today's information age organizations, innovation has not only an intermediary but a direct effect on sustainability (Ardito and Petruzzelli, 2017; Dwivedi et al., 2021). It can be argued that analyzing the digital innovation relationship through career websites will significantly contribute to the relevant literature.

The human relations, technical, and conceptual skills needed by contemporary organizations should be reinforced with a competency-based management approach (Özgül \& Gürol, 2019). Today, various digital innovations are utilized to ensure the sustainability of qualified human resources, especially in a destructive rivalry environment. Digital innovations play an essential role in creating an employee brand for businesses. For this, an essential function in recruitment is to develop digital innovation capabilities such as online recruitment. Here, the ability to develop e-recruitment is the implementation of a system with an improved ability to select human resources. It can be argued that an online recruitment application with enhanced selection ability can make a significant contribution to the sustainability of human resources (App et al., 2012: 267-268).

Social implications. In terms of content, companies share a high rate of education and career information. Companies need to talk about the personnel competencies that certain groups and organizations need to gain an innovative workforce. There is not enough information on the websites about these issues. However, today, especially with the effect of the COVID-19 pandemic, corporate websites have become the primary source of information for job seekers. Job seekers need much information about the job they want to work in during the job searching process. In this process, those who use recruitment materials, namely websites, need information about pay, culture, and career development opportunities and view them as solid predictors of corporate 


\section{INVESTIGATION OF SELECTED COMPANIES' WEBSITES FOR ONLINE RECRUITMENT AND SUSTAINABILITY INDICATORS}

attractiveness (Cober et al., 2003; Williamson et al., 2003). There are generally no third-level links in terms of interaction on the websites; e-mail applications are not accepted; it should be noted that it is crucial for companies and candidates who will apply. In addition, information on the application process and the candidate's stage regarding the position is missing on the web pages. This situation can be evaluated negatively in terms of corporate image. Website content perceived as valuable for job search decision-making needs to provide a logical navigable flow.

Practical implications. Giving the recruitment processes in diagrams makes the process more comprehensible. Organizations have a high percentage of online applications, but no company accepts general applications in the job application sections of their websites. Acceptance of the general application may create a negative perception. Organizations need to have clear information about when and how general applications will be evaluated. A website should have pictures, vivid colors, animation, and sound that give it an aesthetic feature (Williamson et al., 2003). When the web pages of the companies forming the sample are examined formally, it is seen that the rate of animation usage is meager, the profile of people with various racial characteristics is almost not included, and the use of audio and video is not sufficient. Companies accept applications through third-party career websites, apart from their human resources websites. All companies in the index use the website kariyer.net. Thousands of employers advertise their vacancies through these portals and websites (Koçer and Özksüz, 2015; Akduman, 2019). With new generation technologies in job search and recruitment processes, kariyer.net brings job seekers and employers together in an online platform. It is understood that sustainable companies trust the content structure of this web page.

Promoting the stable, inclusive, and sustainable economic growth, full and productive employment, and a decent work for all are among the sustainability goals of the United Nations. It is stated that while realizing this target, development-oriented policies that support productive activities, creating decent employment, entrepreneurship, creativity, and innovation should be supported. Organizations within the scope of the research state in their sustainability reports that they have taken some measures to protect and develop human resources within the scope of innovation and R\&D studies. They state that they evaluate the innovative ideas of their human resources by developing innovative projects. However, sustainability reports, where employees are seen as an essential capital, may not be fully known by job applicants. The messages contained herein are essential in terms of corporate image and attractiveness. Therefore, it should be featured more prominently in the human resources and career pages. For this, online platforms should be established to access and communicate employees and potential employee candidates to Human Resources. In this context, few sustainable companies have innovative platforms. Especially during the pandemic period, it can be easier to manage employees online through these platforms.

Limitations and recommendations for further research. This research is limited to the role of digital innovation in sustainable human resources. In this study, the sustainability of human resources, the corporate sustainability determined by the United Nations, has been examined only through web pages. Apart from these, besides the sustainability of human resources, there are other environmental and individual factors such as job satisfaction, organizational health, organizational culture, organizational conflict, but these issues were not addressed in this study. The inclusion of these organizational behavior variables in future studies may benefit advancing the subject. As a result, the present research is descriptive statistical research and was carried out depending on secondary sources. It may be useful to support the research with quantitative and qualitative 
Hasan TUTAR \& Gamze AY, 2021 Cilt: 22, Sayı: 2, ss.456-479.

research to obtain the opinions of company representatives on the subject in terms of determining employee satisfaction. 


\section{INVESTIGATION OF SELECTED COMPANIES' WEBSITES FOR ONLINE RECRUITMENT AND SUSTAINABILITY INDICATORS \\ REFERENCES}

Akduman, G. (2019). Dijital İşe Alım: Dijital Dünya'nın İnsan Kaynakları İşe Alım Fonksiyonuna Etkisinin Kavramsal ve Uygulama Örnekleriyle Değerlendirilmesi. International Journal of Arts and Social Studies, 2(3), 24-44.

App, S., Merk, J., \& Büttgen, M. (2012). "Employer Branding: Sustainable HRM as a Competitive Advantage in the Market for High-Quality Employees". Management Revue, 23(3), 262278. https://www.jstor.org/stable/41783721

Ardito, L., \& Petruzzelli, A.M. (2017), "Breadth of External Knowledge Sourcing and Product Innovation: The Moderating Role of Strategic Human Resource Practices". European Management Journal, 35(2), 261-272. https://doi.org/10.1016/j.emj.2017.01.005

Batista, A. A. D. S., \& Francisco, A. C. D. (2018). Organizational Sustainability Practices: A Study of the Firms Listed by the Corporate Sustainability Index. Sustainability, 10(1), 226. https://doi.org/10.3390/su10010226

Bednarczuk, P., \& Wendeburg, N. (2008). Talentmanagement, In: Meifert, Matthias T. (Ed.): Strategische Personalentwicklung: Ein Programm in acht Etappen, 1st edition, Berlin, Heidelberg, p. 199-220.

Bejtkovský, J., Rózsa, Z., \& Mulyaningsih, H. D. (2018). A Phenomenon of Digitalization and ERecruitment in the Business Environment. Polish Journal of Management Studies, 18(1), 58-68. https://doi.org/10.17512/pjms.2018.18.1.05

Bilan, Y., Hussain, H. I., Haseeb, M., \& Kot, S. (2020). Sustainability and Economic Performance: Role of Organizational Learning and Innovation. Engineering Economics, 31(1), 93-103.

Borsa İstanbul (2021, 6 December). https://www.borsaistanbul.com/tr

$\begin{array}{llllll}\text { Borsa İstanbul (2021, } & 6 & \text { December). } & \text { Sürdürülebilirlik } & \text { Endeksi }\end{array}$ https://www.borsaistanbul.com/tr/sayfa/165/bist-surdurulebilirlik-endeksi

Breaugh, J. A., \& Starke, M. 2000. Research on Employee Recruitment: So Many Studies, so Many Remaining Questions. Journal of Management, 26(3): 405-435. https://doi.org/10.1177/014920630002600303

Cappelli, P. (2001). Making the Most of Online Recruiting. Harvard Business Review, 79(3), 139148.

Capra, F. (2015). "The Systems View of Life; A Unifying Conception of Mind, Matter, and Life". Cosmos and History. The Journal of Natural and Social Philosophy, 11 (2), 242-249. http://cosmosandhistory.org/index.php/journal/article/view/503

Cho, H., Lee, P., \& Shin, C.H. (2019), "Becoming a Sustainable Organization: Focusing on Process, Administrative Innovation and Human Resource Practices". Sustainability, 11(13), 3554-3571. https://doi.org/10.3390/su11133554

Cober, R. T., Brown, D. J., \& Levy, P. E. (2004). Form, Content, and Function: An Evaluative Methodology for Corporate Employment Websites. Human Resource Management: Published in Cooperation with the School of Business Administration, The University of Michigan and in alliance with the Society of Human Resources Management, 43(2-3), 201218. https://doi.org/10.1002/hrm.20015 
Cober, R. T., Brown, D. J., Keeping, L. M., \& Levy, P. E. (2004). Recruitment on the Net: How Do Organizational Web Site Characteristics Influence. Journal of Management, 30(5), 623646. https://doi.org/10.1016/j.jm.2004.03.001

Cober, R. T., Brown, D. J., Keeping, L. M., \& Levy, P. E. (2004). Recruitment on the Net: How Do Organizational Web Site Characteristics Influence Applicant Attraction? Journal of Management, 30(5) 623 - 646. https://doi.org/10.1016/j.jm.2004.03.001

Cober, R. T., Brown, D. J., Levy, P. E., Cober, A. B., \& Keeping, L. M. (2003). Organizational Web Sites: Web Site Content and Style as Determinants of Organizational Attraction. International Journal of Selection and Assessment, 11(2-3), 158-169. https://doi.org/10.1111/1468-2389.00239

Dwivedi, P., Chaturvedi, V., \& Vashist, J. K. (2021). Innovation for Organizational Sustainability: The Role of HR Practices and Theories. International Journal of Organizational Analysis. https://doi.org/10.1108/IJOA-07-2021-2859

Ehnert, I. (2009). Sustainability and Human Resource Management: Reasoning and Applications on Corporate Websites. European Journal of International Management, 3(4), 419-438. https://doi.org/10.1504/EJIM.2009.028848

Esen, D., \& Esen, M. (2018). Türkiye' de Yayınlanan Sürdürülebilirlik Raporlarının Sürdürülebilir İnsan Kaynakları Yönetimi Bağlamında İncelenmesi: Nitel Bir Araştırma. Uluslararası İktisadi ve İdari Incelemeler Dergisi, (17. UİK Özel Say1s1), 827-844. https://doi.org/10.18092/ulikidince.433623

Esen, D., \& Özer, P. S. (2020). Sustainable Human Resources Management (hrm) A Study in Turkey Context and Developing a Sustainable Hrm Questionnaire. Uluslararası Yönetim İktisat ve Işletme Dergisi, 16(3), 550-580. https://doi.org/10.17130/ijmeb.798548

Esfahani, S. A., Rezaii, H., Koochmeshki, N., \& Parsa, S. S. (2017). Sustainable and Flexible Human Resource Management for Innovative Organizations. AD-minister, (30), 195-215.

Guerci, M., \& Pedrini, M. (2014). “The Consensus Between Italian HR and Sustainability Managers on HR Management for Sustainability-Driven Change - Towards A 'Strong' HR Management System”. The International Journal of Human Resource Management, 25(13), 1787-1814. https://doi.org/10.1080/09585192.2013.860388

Holm, A. B. (2012). E-Recruitment: The Move Towards a Virtually Organized Recruitment Process1. In Human Resource Management in the Digital Economy: Creating Synergy Between Competency Models and Information (pp. 80-95). IGI Global.

https://dergipark.org.tr/en/pub/asstudies/issue/57140/806420

James, P., Magee, L., Scerri, A., \& Steger., M. (2015). Urban Sustainability in Theory and Practice. Routledge. 1.

Kamal, A. H. M. (2020). Sustainable Human Resource Management. Daffodil International University Mba Thesis Report.

Kapse, A. S., Patil, V. S., \& Patil, N. V. (2012). E-Recruitment. International Journal of Engineering and Advanced Technology, 1(4), 82-86. 


\section{INVESTIGATION OF SELECTED COMPANIES' WEBSITES FOR ONLINE RECRUITMENT AND SUSTAINABILITY INDICATORS}

Koçer, S., \& Öksüz, G. (2015). Elektronik İşe Alma Sürecinde Özel İstihdam Bürolarının Rolü: Adecco Türkiye ve Kariyer.net İncelemesi. Uluslararası Yönetim İktisat ve İşletme Dergisi, 11(24), 181-203. https://doi.org/10.17130/ijmeb.2015.11.24.690

Lazaretti, K., Giotto, O. T., Sehnem, S., \& Bencke, F. F. (2020). Building Sustainability and Innovation in Organizations. Benchmarking: An International Journal, 27(7), 2166-2188. https://doi.org/10.1108/BIJ-08-2018-0254

Lebekwe, M., \& Güran, R. (2018). Türkiye'de Elektronik İşe Alım Kullanımına Yönelik Bir Araştırma. Marmara Iktisat Dergisi, 2(1), 89-104. https://dergipark.org.tr/en/pub/mje/issue/36764/418740

Ma Prieto, I., \& Pilar Pérez-Santana, M. (2014). "Managing Innovative Work Behavior: The Role of Human Resource Practices", Personnel Review, 43(2), 184-208. https://doi.org/10.1108/PR-11-2012-0199

Magee, L., Scerri, A., James, P., Thom, J. A., Padgham, L., Hickmott, S., ..., \& Cahill, F. (2013). Reframing Social Sustainability Reporting: Towards an Engaged Approach. Environment, Development and Sustainability, 15(1), 225-243. https://doi.org/10.1007/s10668-0129384-2

Maier, D., Maier, A., Așchilean, I., Anastasiu, L., \& Gavriș, O. (2020). The Relationship Between Innovation and Sustainability: A Bibliometric Review of the Literature. Sustainability, 12(10), 4083. https://doi.org/10.3390/su12104083

Mauri-Castello, J., Alonso-Gonzalez, A., \& Peris-Ortiz, M. (2019). Applied Innovation Methodology: A Proposal for a Dynamic, Sustainable Environment for the Generation of Innovation and Knowledge Management Practices in SMEs. In Knowledge, Innovation and Sustainable Development in Organizations (pp. 61-76). Springer, Cham.

Mazzola, B. G., Junior, M. M. O., Esteves, K., \& Mello Bareto, L. F. B. P. (2018). Innovation Management in Micro, Small and Medium-Sized Companies: A Study in a Brazilian Electro-Electronic Cluster. Independent Journal of Management and Production, 9(4), 1354-1371. http://orcid.org/0000-0003-2059-8639

Melane-Lavado, A., \& Álvarez-Herranz, A. (2018). Different Ways to Access Knowledge for Sustainability-Oriented Innovation. The Effect of Foreign Direct Investment. Sustainability, 10(11), 4206. https://doi.org/10.3390/su10114206

Mishra, S., \& Kumar, S. P. (2019). E-Recruitment and Training Comprehensiveness: Untapped Antecedents of Employer Branding. Industrial and Commercial Training. 51(2), 125136. https://doi.org/10.1108/ICT-12-2017-0106

Orsato, R. J., Garcia, A., Mendes-Da-Silva, W., Simonetti, R., \& Monzoni, M. (2015). Sustainability Indexes: why join in? A Study of the 'Corporate Sustainability Index (ISE)' in Brazil. Journal of Cleaner Production, 96, 161-170. https://doi.org/10.1016/j.jclepro.2014.10.071

Özgül, B., \& Gürol, Y. (2019). Kurumsal Sürdürülebilirlikte Sürdürülebilir İnsan Kaynakları Yönetiminin Rolü Üzerine Bir İçerik Analizi. Doğuş Üniversitesi Dergisi, 20(1), 107-126.

Palmer, J. W. (2002). Web Site Usability, Design, and Performance Metrics. Information Systems Research, 13(2), 151-167. https://doi.org/10.1287/isre.13.2.151.88 
Hasan TUTAR \& Gamze AY, 2021 Cilt: 22, Sayl: 2, ss.456-479.

Souza Marques, N., Sbragia, R., Junior, M. D. M. O., \& Borini, F. (2020). Entrepreneur's Background and Product Innovation. Management Research: Journal of the Iberoamerican Academy of Management, 18(2), 153-169. https://doi.org/10.1108/MRJIAM-11-2018-0878

Srivastava, P., \& Bhatnagar, J. (2008), "Talent Acquisition Due Diligence Leading to High Employee Engagement: Case of Motorola India MDB ". Industrial and Commercial Training, 40(5), 253-260. https://doi.org/10.1108/00197850810886496

Taylor, J. (2002). Sustainable Development: A Dubious Solution in Search of a Problem. Cato Institute, 1-49.

Taylor, S., Osland, J., \& Egri, C.P. (2012), “Guest Editors' Introduction: Introduction to HRM's Role in Sustainability: Systems, Strategies, and Practices". Human Resource Management, 51(6),789-798. https://doi.org/10.1002/hrm.21509

Thompson, L. F., Braddy, P. W., \& Wuensch, K. L. (2008). E-recruitment and the benefits of organizational web appeal. Computers in Human Behavior, 24(5), 2384-2398. https://doi.org/10.1016/j.chb.2008.02.014

Tutar, H. (2015). İşletme Yönetimi, Ankara, Seçkin Yayınc1lı.

Tutar, H., \& Erdem, A. T. (2020). Örnekleriyle Bilimsel Araştırma Yöntemleri ve SPSS Uygulamaları. Ankara: Seçkin Yayncılık.

United Nations Development Program. (2021, 6 December) https://www.undp.org/content/undp/en/home/mdgoverview/post-2015-developmentagenda/goal-1/

Van Stolk, C., Staetsky, L., Hassan, E., \& Woo, C. (2012). Management of Psychosocial Risks at Work: An Analysis of the Findings of the European Survey of Enterprises on New and Emerging Risks. Luxembourg: Publications Office of the European Union.

Veloso, E., da Silva, R. C., Trevisan, L., \& Dutra, J. (2020). Technological Innovations in the Work Environment and the Career of the Millennium Generation. Innovation and Management Review, 17(4), 379-394. https://doi.org/10.1108/INMR-05-2019-0070

Waheed, A., Miao, X., Waheed, S., Ahmad, N., \& Majeed, A. (2019), "How New HRM Practices, Organizational Innovation, and Innovative Climate Affect the Innovation Performance in the IT Industry: A Moderated-Mediation Analysis". Sustainability, 11(3), 621-642. https://doi.org/10.3390/su11030621

Williamson, I. O., Lepak, D. P., \& King, J. (2003). The Effect of Company Recruitment Website Orientation on Individuals' Perceptions of Organizational Attractiveness. Journal of Vocational Behavior, 63(2), 242-263. https://doi.org/10.1016/S0001-8791(03)00043-5

Wołodźko, K., \& Woźniak, J. (2017). The Use by Large Polish Organizations of Information About CSR Activities in E-Recruitment. Economics and Sociology, 10(2), 47. https://doi.org/10.14254/2071-789X.2017/10-2/4

Zhang, Y., Khan, U., Lee, S., \& Salik, M. (2019). The Influence of Management Innovation and Technological Innovation on Organization Performance. A Mediating Role of Sustainability. Sustainability, 11, 495. https://doi.org/10.3390/su11020495 


\section{INVESTIGATION OF SELECTED COMPANIES' WEBSITES FOR ONLINE RECRUITMENT AND SUSTAINABILITY INDICATORS}

Zusman, R. R., \& Landis, R. S. (2002). Applicant Preferences for Web-Based Versus Traditional Job Postings. Computers in Human Behavior, 18(3), 285-296. https://doi.org/10.1016/S0747-5632(01)00046-2 
Hasan TUTAR \& Gamze AY, 2021 Cilt: 22, Sayl: 2, ss.456-479.

\section{EXTENDED ABSTRACT}

Sustainability is the ability to perpetuate and refers to perpetuating the civilization attained by humanity in the $21 \mathrm{st}$ century. The concept of sustainability is also used for directing technological development, directing investments, maintaining institutional change in harmony and also not exploiting resources. The 17 development goals of sustainability have been determined as follows (undp.org): poverty, food, health, education, women's issues, water and sewerage services, energy, economic problems, infrastructure problems, inequality, settlement, consumption, climate, marine life, ecosystems, institutions, and sustainability. It is emphasized that implementation tools should be developed to achieve these goals. This research has been developed depending on the institution's parameters of sustainability determined by the United Nations. The main objective of corporate sustainability has been to promote peaceful and inclusive services, ensure everyone's access to justice, and establish effective, accountable, and inclusive institutions at all levels. For this purpose, the types of activities developed by the institutions, the research sample, were analyzed through the companies' websites with the BIST sustainability index.

In the research, examining the career websites of corporate companies developed by Cober et al. (2004) was used. In the research, human resources and career websites of companies included in the Borsa Istanbul (BIST) Sustainability Index were examined, as they were suitable for the purpose and questions of the research. Cober et al. (2004) analyzed a career website; in terms of content, function, and form. In this research, the companies' web page structural samples were examined regarding the content in question. The BIST Sustainability Index has been created that includes companies traded in Borsa Istanbul and whose corporate sustainability performances are high (https://www.borsaistanbul.com/tr/).

The human resources and career pages of 58 companies in the BIST sustainability index list were analyzed in terms of form, content, and functionality. $69 \%$ of organizations briefly mentioned a remuneration policy. Organizations stated that they determine the remuneration according to collective bargaining agreements, unions, market conditions, and performance and rewarding criteria. Although some companies mentioned the bonuses made throughout the year, no company mentioned the income earned. Therefore, an indication of fees may be preferable. The rate of mentioning social opportunities and fringe benefits other than wages such as nursery, transportation, meals, communication, and annual leave due to working hours, social activity areas, private health insurance, and occupational health insurance is $79 \%$.

$97 \%$ of businesses mentioned career opportunities of their employees. Only $32 \%$ of sites include the definitions and responsibilities of the jobs to be done. Some websites describe a typical working day, and some share videos featuring employees. Under the heading of compatibility, $81 \%$ of the websites contain information groups under the links of students, recent graduates, professionals, or experienced. $69 \%$ of the companies surveyed stated that they do not look at employment only with the profit motive and include various programs to make their employees feel good. $76 \%$ of the companies mentioned that they offer equal employment opportunities. The statements that the employees other than the executive group shared their experiences were found in $36 \% .59 \%$ of the companies surveyed mentioned the self-assessment tests, ability tests, general tests, and foreign language knowledge they applied during the evaluation processes of the candidates. The number of companies that talk about their voluntary services related to social responsibility is $91 \%$. 


\section{INVESTIGATION OF SELECTED COMPANIES' WEBSITES FOR ONLINE RECRUITMENT AND SUSTAINABILITY INDICATORS}

57 of the 58 companies on the sustainability website included in the research have a human resources or career page and a menu link. Thirty-nine of the companies provide information about the application process. Fifty-three companies accept online applications. Twenty-four of the companies make explanatory statements to the candidates about the stage in the online application process. All companies accept applications through third-party digital career websites, except for their websites. Companies are trying to attract human resources from the web page kariyer.net within the scope of digital innovation.

Visual elements were included on the websites of $91 \%$ of the companies in the sample group. The subjects that are particularly emphasized on the websites are made through videos where employees share their experiences, images of the products produced, pictures of entertaining events inside and outside the organization, and images of the working environment. With these visual elements, it is aimed to create a positive perception in the selection of human resources. The messages conveyed on the websites where these elements are used are prepared in a more understandable form. It becomes difficult to understand the messages on websites that are used entirely with text content. $98 \%$ of the companies used different images and colored backgrounds$27 \%$ used moving pictures and links. Video recording was used on $64 \%$ of websites. In these video recordings, some videos convey organizational introductions, videos containing employee experiences, activities within the scope of social responsibility, and fun work environment opportunities that can provide work-life balance.

In this research, online recruitment practices of sustainable organizations within the scope of digital innovation were analyzed. It is essential for researchers and practitioners interested in electronically innovated Web-based recruitment practices to create high-quality human resource pools. To evaluate the companies forming the sample, the snapshots of their webpages were analyzed in form, content, and functionality. These factors have been used to form a basis for websites' relationship with sustainability. In addition, the shares of the companies in the research about their innovation studies were examined. It has been determined that some of the sustainable companies' web pages lack information about wages and additional incomes and rights, job descriptions, entertaining aspects of working life that can help work and social life harmony, opinions of staff about their experiences, and self-evaluation tools. In addition, it has been determined that companies present some information about themselves, such as culture, education, diversity, and social responsibility, on their web pages, but they give less information about wages and other material rights.

In terms of content, companies share a high rate of education and career information. Companies need to talk about the personnel competencies that certain groups and organizations may need to gain an innovative workforce. There is not enough information on the websites about these issues. However, today, especially with the effect of the pandemic, corporate websites have become the primary source of information for job seekers. Job seekers need much information about the job they want to work during the job search process. In this process, those who use recruitment materials, namely websites, need information about pay, culture, and career development opportunities and view them as strong predictors of corporate attractiveness (Cober et al., 2003; Williamson et al., 2003).

Giving the recruitment processes in diagrams makes the process more comprehensible. Organizations have a high percentage of online applications, but no companies accept general applications in the job application sections of their websites. Acceptance of the general application may create a negative perception. Organizations need to have clear information about when and 
Hasan TUTAR \& Gamze AY, 2021 Cilt: 22, Sayl: 2, ss.456-479.

how general applications will be evaluated. A website should have pictures, vivid colors, animation, and sound that give it an aesthetic feature (Williamson et al., 2003).

Companies accept applications through third-party career websites, apart from their human resources websites. All companies in the index use the website kariyer.net. Thousands of employers advertise their vacancies through these portals and websites (Koçer and Özksüz, 2015; Akduman, 2019). With new generation technologies in job search and recruitment processes, kariyer.net brings job seekers and employers online. It is understood that sustainable companies trust the content structure of this web page.

Sustainable practices that can provide change through benevolence, social integration, competencies, and career development are also related to sustainable human resources (Guerci \& Pedrini, 2014; Özgül \& Gürol, 2019). Another aspect of "sustainable human resources" is that it is directly related to organizational innovation. For today's information age organizations, innovation has not only an intermediary but a direct effect on sustainability (Ardito and Petruzzelli, 2017; Dwivedi et al., 2021). It can be argued that analyzing the digital innovation relationship through career websites will significantly contribute to the relevant literature.

Organizations within the scope of the research state in their sustainability reports have taken some measures to protect and develop human resources within the scope of innovation and R\&D studies. They state that they evaluate the innovative ideas of their human resources by developing innovative projects. However, sustainability reports, where employees are seen as an essential capital, may not be fully known by job applicants. The messages contained herein are essential in terms of corporate image and attractiveness. Therefore, it should be featured more prominently in the human resources and career pages. For this, online platforms should be established to provide access and communication between employees and potential employee candidates and Human Resources. In this context, very few sustainable companies have innovative platforms. Especially during pandemic periods, it can be easier to manage employees online through these platforms. 